\title{
Preparation and Evaluation of New LAT1-Targeted USPION to Improve Sensitivity and Specificity in Metabolic Magnetic Imaging of Breast Cancer
}

\section{Rahimeh Rasouli $^{1 \text {,* }}{ }^{\text {ID }}$, Cordula Grüttner ${ }^{2}$, Mehdi Shafiee Ardestani ${ }^{3}$ (D) Reza Faridi-Majidi $^{4}$ (D)}

1 Department of Medical Nanotechnology, International Campus, Tehran University of Medical Sciences, Tehran, Iran

2 Micromod Partikeltechnologie GmbH, Friedrich-Barnewitz-Str. 4, D-18119 Rostock, Germany

3 Department of Radiopharmacy and Medicinal Chemistry, Faculty of Pharmacy, Tehran University of Medical Sciences, Tehran

4 Department of Medical Nanotechnology, School of Advanced Technologies in Medicine, Tehran University of Medical Sciences, Tehran, Iran

* Correspondence: r-rasouli@razi.tums.ac.ir;

Scopus Author ID 55630317300

Received: 10.09.2020; Revised: 8.10.2020; Accepted: 10.10.2020; Published: 14.10.2020

Abstract: The purpose of this study was the investigation of the targeting potential of tyrosineconjugated ultra small superparamagnetic iron oxide nanoparticles (USPIONs) as a new targeted nanocontrast agent for application in molecular magnetic resonance imaging (MRI) of breast cancer. Recently, studies demonstrated that L-type amino acid transporters (LAT1) are highly expressed in breast cancer cells. Thus, LAT1 targeting via tyrosine as a LAT1 substrate could improve the sensitivity and specificity of this nanosized contrast agent. To achieve this goal, USPIONs were conjugated to tyrosine and characterized using DLS and FT-IR. The cell viability was measured in different concentrations of nanoparticles $(0.6,1.2,2.4 \mathrm{mM})$ in breast cancer cells (MDA231, MCF7,4T1) and control cell line (normal kidney cells; HEK293) with the MTT assay. Cellular uptake was evaluated via Prussian blue staining and Inductively Coupled Plasma-Optical Emission Spectroscopy (ICP-OES) as well as by measurement of the reduction of signal intensity using 3Tesla clinical MRI. T2-weighted imaging in tumor-bearing bulb/c mice was performed via brain coil and home-built phantom. The particle size and charge of USPIO significantly changed after the conjugation of tyrosine. According to ICP-OES results from the cellular uptake of tyrosine-USPION in 4T1 cell line and HEK-293was $48.14 \% \pm 1.43$, and $6.91 \pm 0.21$, respectively. The reduction in MRI signal intensity at in vitro studies was higher in the presence of tyrosine-USPION than of USPION. The reduction in MRI signal intensity at in vivo studies was $58.83 \%$ in the presence of tyrosine conjugated USPION compared with plain nanoparticles. Biodistribution studies demonstrated that the accumulation of tyrosine-USPIONs was about seven times higher than that of non-targeted USPIONs after $24 \mathrm{~h}$. In conclusion, tyrosine-USPIO as a new LAT1 targeted contrast agent with high sensitivity and specificity can be suggested as a good and ideal candidate in breast cancer molecular imaging.

Keywords: Breast cancer; LAT1 transporter; Molecular imaging; Tyrosine; MRI; USPION.

(C) 2020 by the authors. This article is an open-access article distributed under the terms and conditions of the Creative Commons Attribution (CC BY) license (https://creativecommons.org/licenses/by/4.0/).

\section{Introduction}

The World Health Organization (WHO) estimated that 84 million death occurred due to cancer between 2005-2015 [1]. The most common type of cancer for women is breast cancer $[2,3]$. 
Worldwide, more than 1 million women with breast cancer are identified annually, and near $14 \%$ of deaths in women are due to this cancer. Furthermore, in developing countries, breast cancer incidence rates are growing by up to $5 \%$ each year $[4,5]$.

Early detection and diagnosis of breast cancer have a significant effect on the survival rate of patients with breast cancer, from the 5-year survival rate of $23.4 \%$ in patients with stage IV disease to $98 \%$ in patients with stage I disease [6].

Many molecules have been identified with important roles in the malignant growth and progression of breast cancer cells; the detailed mechanisms are still not completely cleared. So, there is an essential need to find new powerful tumor-specific biomarkers at the molecular level, which permit to insights into breast cancer diagnosis and treatment [7].

Currently, two groups of receptor-targeted drugs as only molecularly targeted drugs have been utilized for advanced breast cancer treatment, including the HER2-targeting antibody trastuzumab and anti-estrogen drugs such as tamoxifen. There are some important limitations of these drugs; about HER2-targeting antibody, just about $25 \%$ of patients with breast cancer exhibit HER2/neu upregulation, and a response rate of the administration of trastuzumab is only $21 \%$ [8,9]. Another group is estrogen receptor-drugs, approximately 55\% ratio in breast cancer tumors are estrogen receptor-positive, but there are high positive ratios of estrogen receptors in normal and benign breast tissues as well [10].

Molecular imaging based on the metabolism of tumor cells has shown significant success in breast cancer diagnosis, staging, as well as treatment of patients[11]. Molecular imaging can diagnose tumor-specific features at molecular levels and provide information about the functional state of the tumor tissue.

Many researchers have revealed that malignant tumors can be identified with high sensitivity and specificity by their increased metabolic rates for glucose[12-14], lipids(1Ccholine and ${ }^{18} \mathrm{~F}$-fluorocholine) [15], or amino acids [16] via imaging.

Although, PET with the ${ }^{18} \mathrm{~F}$-labeled fluoro-2-deoxyglucose $\left({ }^{18} \mathrm{~F}\right.$-FDG-PET), is used as a gold standard in a clinical test for staging and restaging analog of malignant lymphoma and most solid tumors $[12,13]$.

Unfortunately, some important limitations of ${ }^{18} \mathrm{~F}-\mathrm{FDG}$ are false positive/negative diagnosis, delivery of poor predictive values of tumor response to chemo/radiotherapy, and poor contrast in brain tumor as well as poor differentiation of tumor from inflammatory tissue [14].

Amino acids are required for rapid growth and proliferation of tumor cells due to their function as the basic building blocks of proteins and as carbon and nitrogen source for the synthesis of glutathione, amino sugars, pyrimidine, and purine nucleotides [17,18].

In the development of amino acid-based imaging probes, the main focus is directed on system L and/or A amino acid transporters -the two main transport systems in mammalian cells [11].

PET with ${ }^{18} \mathrm{~F}$-labeled amino acids as another radiotracer has been investigated because actively proliferating tumor cells ingest more nutrients, such as amino acids. The upregulation of amino acid transporters generally occurs to facilitate amino acid uptake for tumor cells. Previous studies have revealed a relationship between LAT1 level and tumor growth [19,20]. Therefore, the rate of amino acid uptake and transport can be employed as a tumor-specific biomarker $[11,18]$.

System L (L-type amino acid transporter system, or LAT) has four subtypes called LAT1-4 as a $\mathrm{Na}^{+}$-independent amino acid transporter system. LAT is essential for the transport 
of large, neutral amino acids, such as aromatic amino acids or branched [17,21,22]. Among these four subtypes, only LAT1 shows increased transport activity and plays an important role in tumor cell growth. LAT1 overexpression has been proved in several cancer types as well as tumor cell lines such as Barrett's adenocarcinoma [23], astrocytic tumors [24,25], oral cancer [26], lung adenocarcinoma [27], esophageal carcinoma [28], osteogenic sarcoma cells [29], KB human and oral epidermoid carcinoma cells [30]. Therefore, it is considered as a diagnostic and prognostic biomarker for cancers [23-27,29-40].

Up to now, several studies have demonstrated the role of highly specific LAT1 upregulation in breast cancer cell lines [11,41-46]. Among the LAT subtypes, only LAT1 shows increased transport activity and promotes the proliferation, tumorigenesis, and progression of breast cancer cells [45]. LAT1 has several unique properties such as homogenous expression of LAT1 in breast tumor tissue, about $94 \%$ of breast tumor tissues are LAT1 positive, and LAT1 is not detectable in normal breast tissues [41]. These findings offer that LAT1 can be a potential biomarker for breast cancer diagnosis and treatment [45].

There are many researches with LAT1 transporter-targeted nanoparticles that demonstrated the definitive potential to transfer across biological barriers with high uptake of contrast agents and therapeutic drugs in a targeted cell with high sensitivity and specificity [37,47-62]

Recently, several studies have been demonstrated the effectiveness of LAT-1 targeting for drug and contrast agents delivery in a wide range of cancers like breast cancer and glioma [49,51,52,54,63-65].

It was reported that the functionalizing of polyoxyethylene stearate PLGA nanoparticles with glutamate as a LAT-1 targeting substrate to paclitaxel delivery caused significantly higher tumor accumulation and inhibition of tumor growth in a subcutaneous 4T1 breast carcinoma mouse tumor model in comparison to non-functionalized nanoparticles [51].

LAT is the only transporter system that is able to enter large neutral amino acids with aromatic rings such as tyrosine, tryptophan, and phenylalanine $[11,46]$. In general, among all amino acids, aromatic amino acids are more suitable for tumor imaging due to their unique features, such as easier chemical modification and characterization [11].

Among radiotracers, ${ }^{18} \mathrm{~F}$-labeled tyrosine and its derivatives have shown high tumor uptake and accumulation via L-type amino acid transporters (LAT), which were reported to be highly expressed in various cancer cell lines and correlate positively with tumor proliferation.

L-tyrosine is a biologically important substrate for proteins, thyroid hormones, and also catecholamine as well as melanin synthesis after hydroxylation[66]. L-tyrosine has been used as a reliable amino acid-based PET probe for tumor diagnosis and quantification in multiple types of malignancies, including lung, soft tissue sarcomas, brain, head, and neck cancers as well as breast cancer [11,45,67-71].

Kong et al. demonstrated a positive correlation between ${ }^{99 \mathrm{~m}} \mathrm{Tc}-\mathrm{EC}-\mathrm{Ty}$ rosine analog, 99m Tc tyrosine using N,N'-ethylene-di-L-cysteine (EC) as a chelator, uptake in breast tumors, LAT1expression and breast tumor cell malignancy, so ${ }^{99 \mathrm{~m}} \mathrm{Tc}-\mathrm{EC}-\mathrm{Tyrosine}$ can be considered as the most suitable radiotracer for breast cancer imaging [67]. These findings offered that tyrosine can be a potential biomarker for noninvasively assessing LAT1 function, which correlates well with breast cancer malignancy and metabolism. 
Based on these observations, we hypothesized that the conjugating of a tyrosine as LAT-1 targeting moieties on USPIONs would selectively increase nanoparticle accumulation inside tumor cells for the imaging of breast cancer.

Several modalities such as single-photon emission computed tomography (SPECT), positron emission tomography (PET), computed tomography scan (CT), and magnetic resonance imaging (MRI) has been used in the metabolic imaging [72-76]. MRI is also a highly suitable modality for molecular imaging due to its high spatial resolution and excellent softtissue contrast [77]. Toxicity, low specificity, and selectivity are some limiting of currently used magnetic contrast agents. To overcome these restrictions, a high concentration of contrast agents is required at the target site by identifying specific molecules that are overexpressed in certain cancerous regions. The application of nanomaterials has been opened a promising window for disease diagnosis and therapy [78-87]. Recent progress in nanotechnology has enhanced the properties of $\mathrm{T} 1$ and $\mathrm{T} 2$ contrast agents for these biomedical applications $[49,88$ 90]. Ultrasmall superparamagnetic iron oxide nanoparticles (USPION) were broadly employed in MRI as a versatile ultra-sensitive nanoprobe for molecular and cellular imaging of cancers. Carrier mediated transport, and receptor-mediated transcytosis are aims of carriers or drugs which were conjugated to amino acids, glucose, and nucleosides or bigger molecules like insulin and transferrin [91,92].

As many types of breast cancer cells have high expression of LAT1 on their cell surface, the imaging strategy is using USPIONs conjugated to LAT1 substrate (tyrosine as a targeting ligand) to improve sensitivity and specificity of this contrast agent in LAT1-expressing breast cancer cells.

The goal of this study is the evaluation of the targeting potential of USPION-tyrosine conjugate as a new LAT1-targeted nanoparticle-based contrast agent with high sensitivity, specificity, and no toxicity for breast tumor MR imaging.

\section{Materials and Methods}

\subsection{Materials.}

Nanomag®-CLD-spio nanoparticles were provided from Micromod (MicromodPartikeltechnologie $\mathrm{GmbH}$, product code: 77-02-201). These nanoparticles were crosslinked dextran-coated USPION with $\mathrm{COOH}$ functional groups on their surface. The solid concentration of the nanoparticles and their iron concentration were 5 and $2.4 \mathrm{mg} / \mathrm{ml}$, respectively. The magnetic cell sorting columns (MACS® separator with MS columns) were purchased from Miltenyi Biotec GmbH (Gladbach, Germany). All other chemical reagents were supplied by Sigma-Aldrich Chemical Co.

Highly human and mice malignant breast cancer cell lines: MDA-MB-231, MCF7, 4T1, and a non-tumorigenic kidney cell line (HEK 293) have been used, which were purchased from National Cell Bank of Iran (Pasteur Institute, Tehran, Iran).

\subsection{Cell culture.}

MDA-MB-231, MCF7, and 4T1 cell lines, as well as HEK 293cell line, were grown using complete RPMI-1640 and Dulbecco's Modified Eagle Medium (DMEM), respectively, supplemented with $10 \%$ fetal bovine serum and $1 \%$ penicillin-streptomycin at $37^{\circ} \mathrm{C}$ with $5 \%$ $\mathrm{CO}_{2}$. 


\subsection{Mouse model with breast tumor.}

The animal experiments were performed with BALB/c mice (6-8 weeks old with a mean weight of 16-18 g). The breast tumor was formed by injecting $1 \times 10^{6}$ cells in a final volume of $0.1 \mathrm{ml}$ injected subcutaneously in the left side of mice. The desirable size of the tumor was obtained2-3 weeks post-injection. All animal experiments were performed in accordance with the guidelines of the INMAS animal ethics committee.

\subsection{Preparation of targeted nano contrast agent.}

\subsubsection{Conjugation of tyrosine on the surface of USPION.}

The tyrosine conjugation on USPIONs was performed following a two-step process (figure 1). The amine group of tyrosine was covalently conjugated to the carboxyl group ofUSPION via an amide bridge. Briefly, the carboxyl groups of USPION were activated with 1-Ethyl-3-(3-dimethylaminopropyl) carbodiimide (EDC), and sulfo-N-hydroxy sulfo succinimide (sulfo-NHS) in 2-( $N$-morpholino) ethane sulfonic acid buffer (MES buffer) by 40 min shaking at room temperature (RT), the excess of sulfo-NHS and EDC was removed by washing with PBS buffer( $\mathrm{pH}$ 7.2) in a magnetic-activated cell sorting (MACS) column. $0.5 \mathrm{ml}$ tyrosine $(40 \mu \mathrm{g} / \mathrm{ml}$ in bicarbonate buffer) was mixed with $0.5 \mathrm{ml}$ suspension of activated USPION in DI water. After shaking for $4 \mathrm{~h}$ at RT, the excess of tyrosine was removed by washing with PBS buffer in a MACS column. Finally, USPION-tyrosine conjugate was dispersed in DI water for characterization and in vitro and in vivo studies.

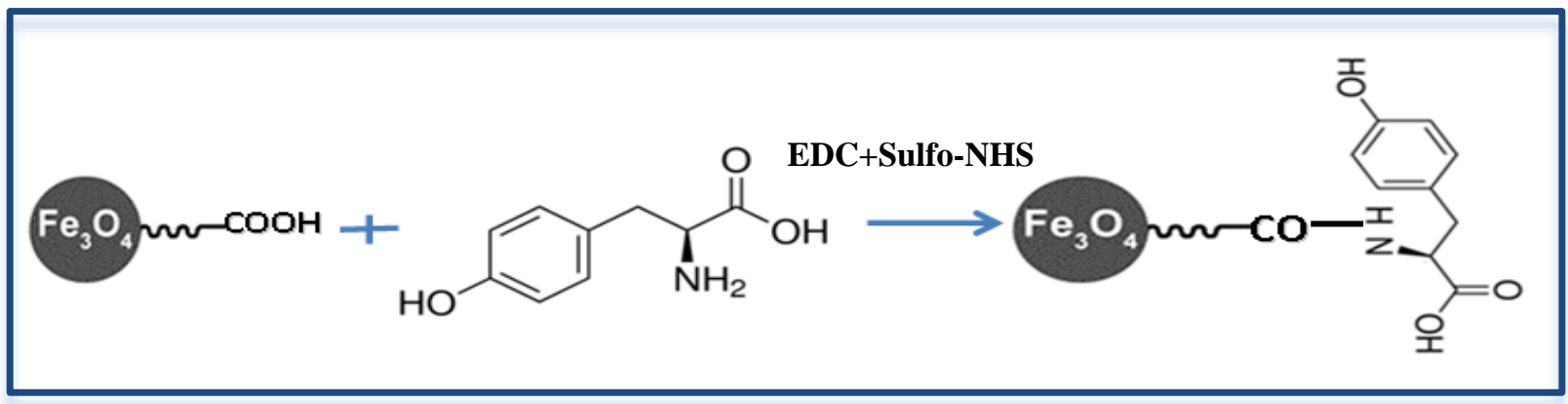

Figure 1. Schematic presentation of the synthesis of USPION-tyrosine conjugate.

\subsubsection{Characterization of nanoparticles.}

Mean size, size distribution, and zeta potential of USPION and USPION-tyrosine conjugate were measured with Zeta sizer Nano ZS (Malvern Instruments Ltd., Malvern, UK). The conjugation of tyrosine on the surface of USPION was verified by the FTIR analyses (NEXUS 870; Thermo Fisher Scientific, Waltham, MA, USA).

\subsubsection{In vitro cytotoxicity assay.}

The in vitro cytotoxic effect of USPION and USPION-tyrosine conjugate was examined via the 3-(4,5-dimethylthiazol-2-yl)-2,5-diphenyltetrazolium bromide (MTT) assay, using highly human and mice malignant breast cancer cell lines: MDA-MB-231, MCF7, 4T1 and a non-tumorigenic kidney cell line (HEK 293) $\left(2 \times 10^{4}\right.$ cells were seeded per well in 96well plates) at different iron concentrations $(0.6,1.2,2.4 \mathrm{mM})$ for $3 \mathrm{~h}$. All experiments were done in triplicate, and cell survivalas determined as a percentage of viable cells in comparison with controls. 


\subsection{Intra-cellular uptake studies.}

2.5.1. In vitro analysis of cell-uptake with ICP-OES measurements.

To determine intra-cellular uptake of iron, 4T1 and HEK cells at a concentration of 4 $\times 10^{6}$ per tube were incubated with a culture medium containing USPION and USPIONtyrosine at iron concentrations of $1 \mathrm{mM}$ for $2 \mathrm{~h}$ at RT. In the next step, cells were washed three times with PBS and digested in $0.5 \mathrm{ml}$ of $\mathrm{HCl}(5 \mathrm{~N})$ for $2 \mathrm{~h}$ in a water bath at $80^{\circ} \mathrm{C}$. Iron concentrations in digested cell samples were measured with ICP-OES. Untreated cells were used as a control [90].

\subsubsection{In vitro analysis of uptake with Prussian blue staining.}

The intra-cellular uptake of USPION and USPION-tyrosine into highly human and mice malignant breast cancer cell lines: MDA-MB-231, MCF7, 4T1, and a non-tumorigenic kidney cell line (HEK 293) was studied by Prussian blue staining. Briefly, $2 \times 10^{5}$ cells per well, in 12-well plate cells were incubated overnight at $37^{\circ} \mathrm{C}$ in a humidified incubator with a $5 \% \mathrm{CO}_{2}$ atmosphere for $24 \mathrm{~h}$ for cell adherence. After that, the cell medium was removed, and cells were washed three times with PBS and incubated with $2 \mathrm{mM} / \mathrm{ml} \mathrm{Fe}$ concentration of each particle type for 2 hat RT. Then treated cells were washed with PBS and fixed in paraformaldehyde (4\%) for $20 \mathrm{~min}$. Then cells were washed three times with PBS and stained using Prussian blue solution (equal volumes of HCL (2\%) and potassium ferrocyanide (II) trihydrate $(2 \%)$. The stained plate images were taken with an inverted microscope [90].

\subsubsection{In vitro analysis of uptake with magnetic resonance imaging.}

The potential of the USPION-tyrosine for MRI was studied in vitro after incubation with $4 \mathrm{~T} 1$ cell line. In brief, each $3 \times 10^{6}$ cells per tube were incubated with USPION and USPION-tyrosine at different concentrations of Fe (10-40 $\mu \mathrm{g})$ for $2 \mathrm{~h}$ at RT. After that, cells were washed three times with PBS and resuspended in agar gel (2\%).

T2-weighted images and signal intensity of samples were measured via 3Tesla clinical MRI via brain coil and home-built phantom with a spin-echo imaging sequence (Siemens, Germany). Imaging parameters were as follows: TR: $1500 \mathrm{~ms}$; TE: 15.3, 30.6, 45.9, 61.2, 76.5, 91.8, 107.1, 122.4, 137.7, $153 \mathrm{~ms}$; FOV:170 mm×170mm.

The data from regions of interest (ROI) were drawn to consistently measure mean signal intensity at the identical position within each phantom vial $[89,90,93]$.

\subsubsection{In vivo MR imaging.}

MR images of Bulb/c mice bearing 4T1 breast cancer cells were taken before and $1 \mathrm{~h}$ after injection of USPION and USPION-tyrosine $(2 \mathrm{mg} / \mathrm{kg})$ into the tail vein. All images were acquired using the T2-weighted imaging method by the spin-echo pulse sequence technique; imaging parameters were as follows: $\mathrm{FOV}=124 \mathrm{~cm} \times 124 \mathrm{~cm}, \mathrm{TE}=89 \mathrm{~ms}, \mathrm{TR}=8000 \mathrm{~ms}$.

MR image signal intensity was determined using the signal intensity of the region of interest $1 \mathrm{~h}$ after injection of both USPION and USPION-tyrosine in tumor region with the Dicom Works version 1.3.5 (Dicom Works, Lyon, France). 


\subsection{Biodistribution studies.}

For biodistribution studies, all bulb/c mice bearing 4T1 breast cancer cells were injected with USPION, USPION-tyrosine, and control (without any injection), ( $n=3$ per group). All mice were sacrificed $24 \mathrm{~h}$ after imaging, and then critical organs (including tumor, spleen, liver, and kidney) of each group were weighed and, after doing acid digestion process, analyzed with ICP-OES to calculate the iron content of each organ. Each ICP-OES experiment was performed at least three times. The percentage of iron content (ppm) of organs was reflected as biodistribution of the USPION and USPION-tyrosine conjugate in the studied organs.

\subsection{Statistical analysis.}

Multi-group comparisons were made by one-way ANOVA. The student t-test was used to compare two group data. Results are mentioned as mean \pm SD.

\section{Results and Discussion}

\subsection{Characterization of nanoparticles.}

The particle size and charge of USPION before and after conjugation with tyrosine was determined by dynamic light scattering (DLS). The results were summarized in Table 1. Following the tyrosine conjugation, a significant change in charge and size was observed. Due to the presence of $\mathrm{OH}$ and $\mathrm{COOH}$ groups in tyrosine after surface modification of USPION, a significant decrease in charge from -14.7 to $-19.9 \mathrm{mv}$ was observed. Also, an increase in particle size was observed after surface modification.

Table 1. Size distributions and zeta potential of the USPION and USPION-tyrosine.

\begin{tabular}{l|l|l} 
Nanoparticles & Size (nm) & Charge \\
\hline USPION & $81.2 \pm 0.8$ & $\mathbf{- 1 4 . 7 \pm 0 . 2}$ \\
\hline USPION-tyrosine & $96.9 \pm 1.1$ & $\mathbf{- 1 9 . 9 \pm 0 . 1}$
\end{tabular}

\subsection{FT-IR result.}

The FT-IR spectrum of USPION-tyrosine conjugate is shown in Figure 2. After an amidation reaction, new peaks that confirmed the presence of amide bond ( $-\mathrm{CO}-\mathrm{NH}-$ ) formed after the conjugation of the $\mathrm{NH}_{2}$ group of tyrosine with the COOH group of USPION. The peak at $1633 \mathrm{~cm}^{-1}$ is related to the carbonyl group of $(\mathrm{C}=\mathrm{O})$ of amide bond.

\subsection{In vitro cytotoxicity of nanoparticles.}

A suitable nanoprobe as a targeted MRI contrast agent should exhibit minimal toxicity to the targeted cell. MTT assay was done in breast cancer cell lines: MDA-MB-231, MCF7, 4T1, and a non-tumorigenic kidney cell line (HEK 293) to evaluate the cytotoxic potential of USPION-tyrosine and USPION with different concentrations. Results exhibited $>75 \%$ cell viability in relation to the control sample, in most cases (Figure 3). From the results obtained, the increase in concentration from 0.6 to $2.4 \mathrm{mM}$, resulted in increased toxicity of tyrosineUSPION. There is no obvious reason for this observation. Previous studies have shown that with an increase in the concentration of the agent, cell viability may either decrease or increase [94-96]. 


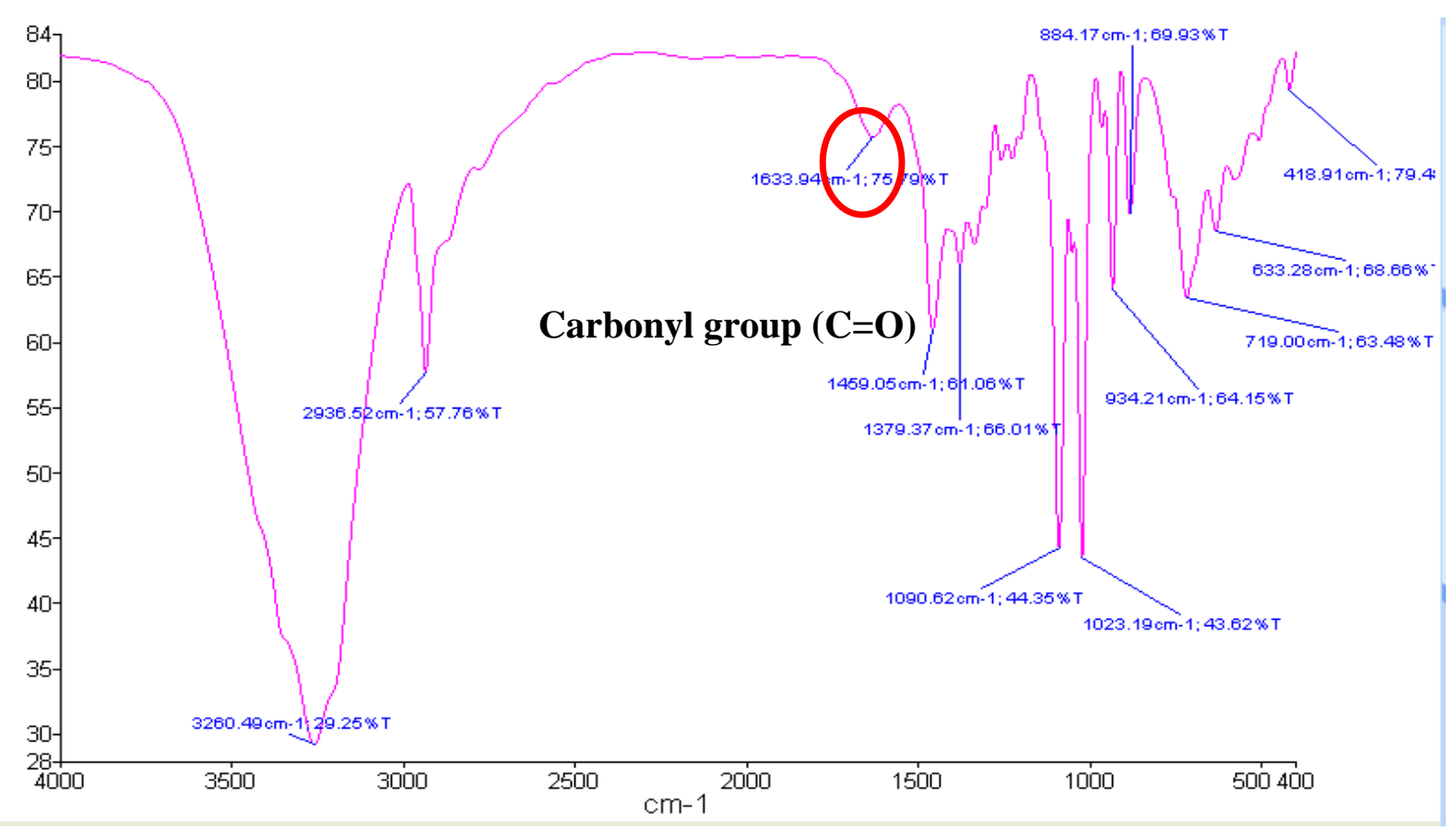

Figure 2. FT-IR spectrum of USPION-tyrosine.

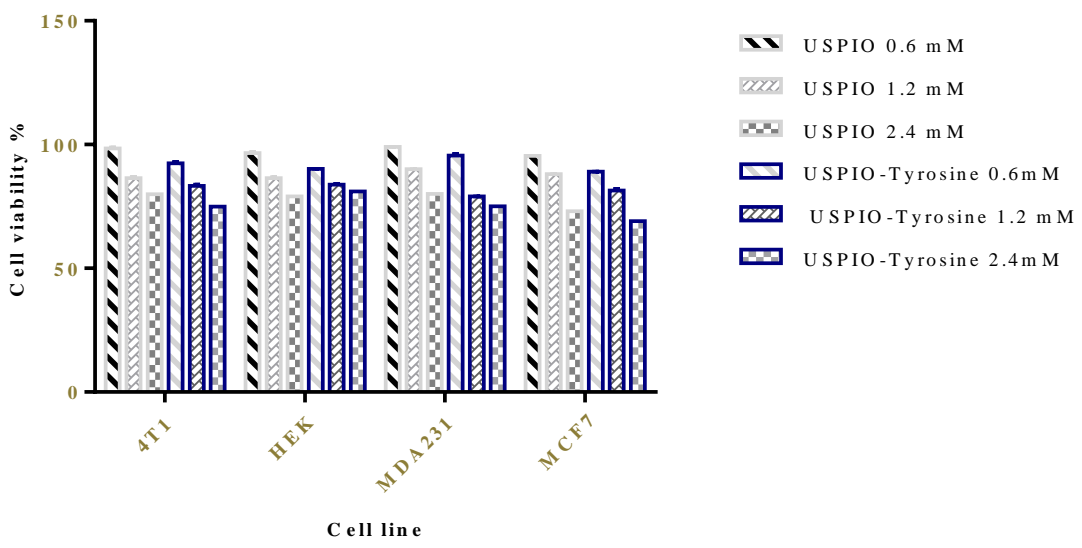

Figure 3. The cytotoxicity effect of USPION and USPION-tyrosine to breast cancer cell lines: MDA-MB-231, MCF7, 4T1, and a non-tumorigenic kidney cell line (HEK 293) was assessed in vitro by the MTT assay. The cells were treated with USPION and USPION-tyrosine at equivalent iron concentrations ranging from 0.6 to 2.4 $\mathrm{mM}$ for $3 \mathrm{~h}$.

\subsection{Cellular uptake studies.}

To determine the ability of tyrosine as a LAT1 substrate to target breast cancer cells, 4T1 cell uptake efficiency of USPION and USPION-tyrosine conjugate was compared with T2-weighted images and signal intensity of samples. USPIONs as negative contrast agents affect $\mathrm{T} 2$ relaxivity and hence decrease signal intensity. Higher intracellular content of $\mathrm{Fe}$ results in the reduction of signal intensity and $\mathrm{T} 2$ relaxation time. The potential of USPIONtyrosine as a specific MR imaging agent was demonstrated by a significant reduction of the MR image signal intensity in the 4T1 cell line compared with the nonspecific agent of USPION (Figure 4). 


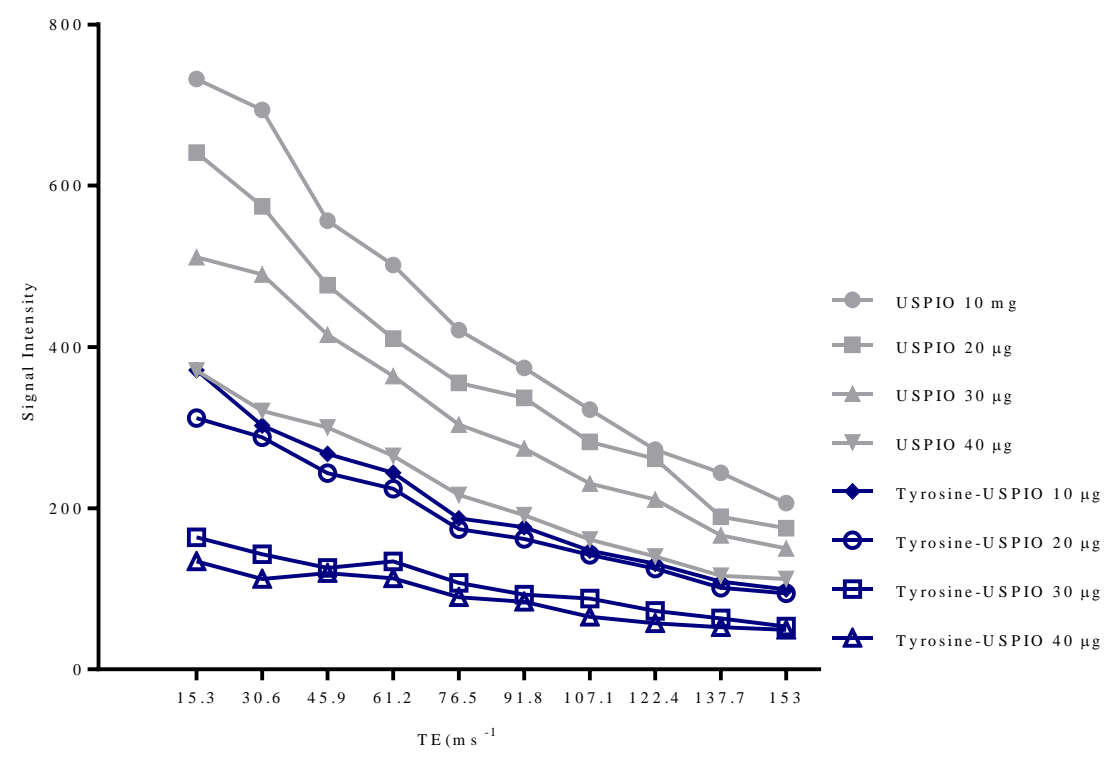

Figure 4. Signal intensity changes in the 4T1 cell line incubated with USPION-tyrosine and USPION at Fe concentration of $10,20,30,40 \mu \mathrm{g} / \mathrm{ml}$. The signal intensity in the 4T1 cell line after incubation significantly decreased by higher cellular uptake of USPION-tyrosine.

Also, iron concentration measurement with ICP-OES of cells after incubation with USPION-tyrosine exhibited significantly increased Fe content in the 4T1 cell with high expression of LAT1 over negative HEK 293 cells. After incubation with USPION-tyrosine and USPION, the intra-cellular Fe content in 4T1 and HEK293 cell lines was shown (Table 2). According to ICP results, tyrosine conjugated nanoparticles enter the cancerous cells 4.63 times more than reference USPION. Intracellular uptake of USPION-tyrosine in the 4T1 cells and normal kidney cells (HEK-293) were $48.14 \% \pm 1.43$ and $6.91 \pm 0.21$, respectively.

Similar results were observed by the study conducted by (Khosroshahi et al. 2013), in which methionine as LAT1 substrate was attached to anionic linear globular dendrimer G2 labeled ${ }^{99 \mathrm{~m}} \mathrm{TC}$. Intra-cellular uptake of ${ }^{99 \mathrm{~m}} \mathrm{Tc}$-DTPA-Met, ${ }^{99 \mathrm{~m}} \mathrm{Tc}-$ Dendrimer-Met in human colon adenocarcinoma grade II cell line (HT29) were 50\% and 60\% respectively after $4 \mathrm{~h}$. The study confirmed better performance following the administration of ${ }^{99 \mathrm{~m}} \mathrm{Tc}$-Dendrimer G2Methionine [48].

Similar to our finding, another study had established that the ability of LAT1 targeting improved when methionine was conjugated on gadolinium-based mesoporous silica nanospheres (Met-MSN-Gd ${ }^{3+}$ ). The in vitro studies on human breast cancer cell lines (MCF7) showed that Met-MSN-Gd ${ }^{3+}$ was taken up by cells 2-7 times more efficiently than the MSN$\mathrm{Gd}^{3+}$ which showed the importance of methionine group in the internalization of Met-MSN$\mathrm{Gd}^{3+.}$ Intra-cellular uptake of Met-MSN-Gd ${ }^{3+}$ in MCF7 and normal kidney cells (HEK-293) were $65.77 \%$ and $2.4 \%$, respectively [97].

Table 2. ICP results of the mean cellular iron contents after treatment of 4 T1and HEK Cell lines USPION and USPIO-tyrosine at an iron concentration of $1 \mathrm{mM}$ for $2 \mathrm{hr}$.

\begin{tabular}{l|l|l} 
Nanoparticle & $\begin{array}{l}\text { 4T1 } \\
\text { Fe concentration (ppm) }\end{array}$ & $\begin{array}{l}\text { HEK } \\
\text { Fe concentration (ppm) }\end{array}$ \\
\hline USPIO & $6.33 \pm 0.30$ & $2.06 \pm 0.04$ \\
\hline USPIO-Tyrosine & $29.37 \pm 1.43$ & $4.22 \pm 0.21$ \\
\hline Control (Untreated cell) & $0.30 \pm 0.11$ & $0.21 \pm 0.08$
\end{tabular}

The targeting specificity of USPION-tyrosine to the positive LAT1 cancer cells was also confirmed with Prussian blue staining. The Blue region (Table 3) represented the LAT1 
targeting effect on cellular uptake efficacy. There was no blue color that appears in the cells incubated with USPION or LAT1 negative (HEK293) cells.

There is no study especially related to the evaluation of cellular uptake via LAT1targeted nanoparticle by Prussian blue staining method. The results obtained are in accordance with previously reported $\gamma$ - $\mathrm{Fe}_{2} \mathrm{O}_{3}$-DMSA-DG NPs (2-deoxy-D-glucose (2-DG) conjugated meso-2,3-dimercaptosuccinic acid-coated $\gamma-\mathrm{Fe}_{2} \mathrm{O}_{3}$ nanoparticles) for glucose transporter targeting in tumor cells. When 2-DG-conjugated and nonconjugated nanoparticles were incubated with Hela cells, the 2-DG-conjugated nanoparticle showed a significant amount of uptake in cells compared to their non-targeted counterparts. UV colorimetric assay showed $\gamma-$ Fe2O3-DMSA-DG NPs internalization were about 2- to 5-fold higher than $\gamma$-Fe2O3-DMSA NPs [98].

Table 3. Prussian blue staining images for highly human and mice malignant breast cancer cell lines: MDAMB-231, MCF7, 4T1, and a non-tumorigenic kidney cell line (HEK 293) after $2 \mathrm{~h}$ incubation with 2mM

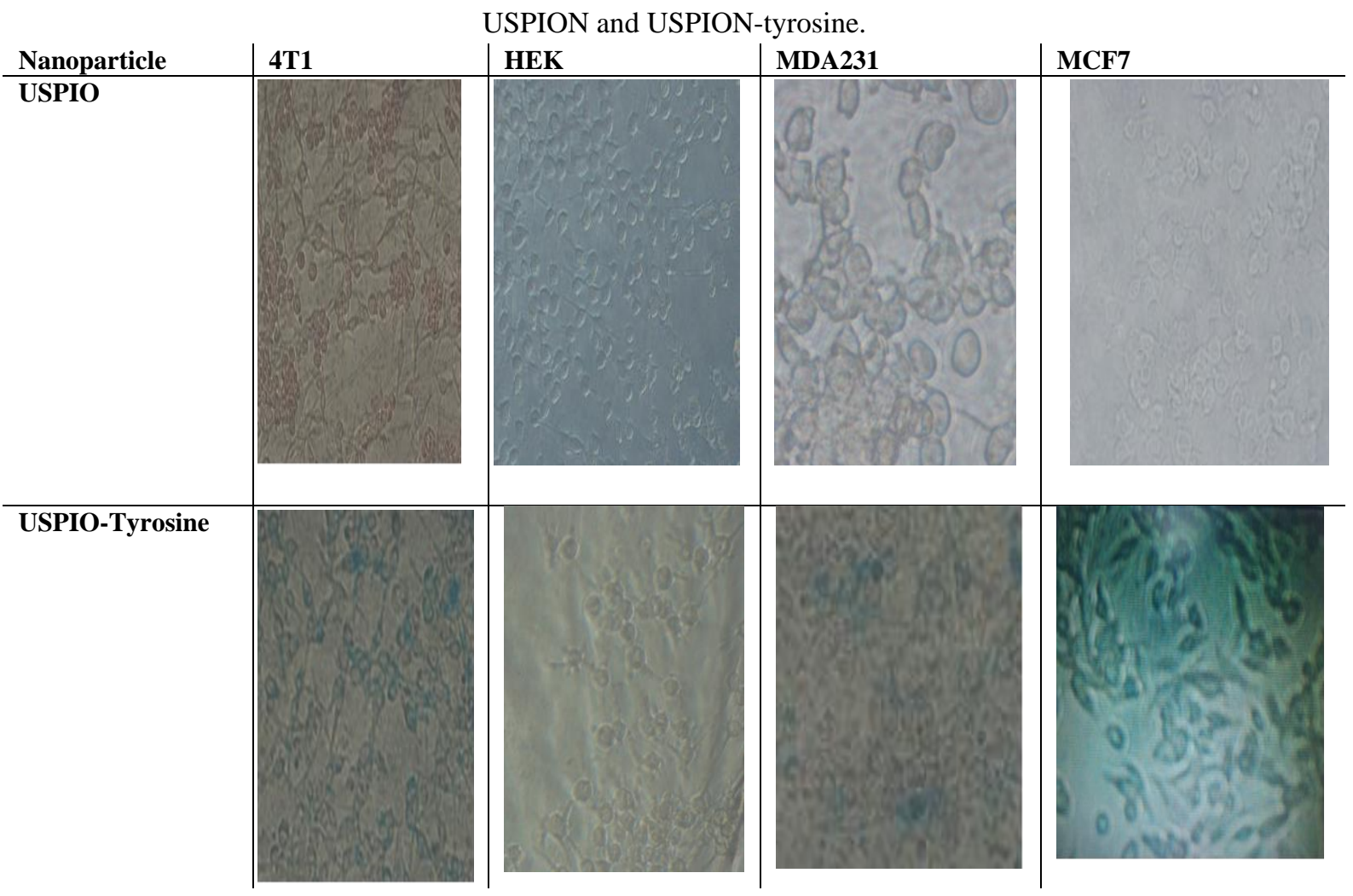

\subsection{In vivo $\mathrm{MR}$ imaging.}

T2-weighted MRI images were taken before and $1 \mathrm{~h}$ after injection of both contrast agents in studied animals (Figure 5). A significant reduction of signal intensities and T2 values of breast cancer tissue was observed after the injection of USPION-tyrosine in comparison with USPION. The amount of reduction in signal intensity in the tumor region, the presence of tyrosine conjugated USPIO nanoparticles was $58.83 \%$ compared with nonconjugated nanoparticles.

Similar results were also observed when methionine was conjugated on gadoliniumbased mesoporous silica nanospheres for breast cancer imaging. The in vivo studies on bulb/c mice bearing 4T1 breast cancer cells showed that the amount of internalized Met-MSN-Gd ${ }^{3+}$ was large enough to yield a significant effect on the MRI signal intensity [97]. 
(a)

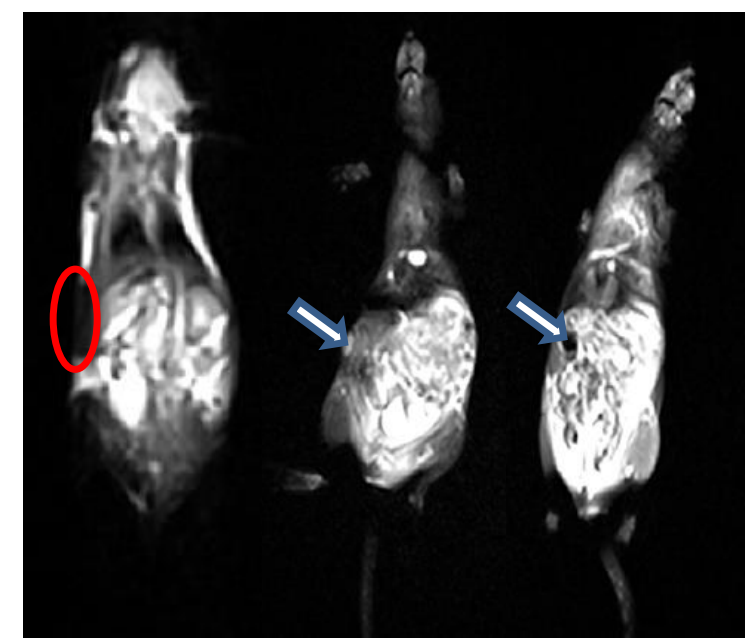

Figure 5. T2-weighted MRI images of Bulb/c mice bearing 4T1 breast cancer cells before and $1 \mathrm{~h}$ after injection of USPIO and USPIO-Tyrosine ( $2 \mathrm{mg} / \mathrm{kg}$ )into the tail vein: (a) before injection of agents, (b) after injection of USPION, and (c) after injection of USPION-tyrosine conjugate, respectively left to right.

\subsection{Biodistribution studies.}

The biodistribution study of these nano contrast agents exhibited dramatic accumulation of the USPION-tyrosine in the tumor region, as illustrated in Table 4. The USPION-tyrosine conjugate accumulation in tumor tissue was about seven times higher than that of USPION after 24h [99]. These results suggest that this USPION-tyrosine conjugate could be suitable for utilizing as LAT1 target agent for the detection of breast cancer and all other cancers with high expression of LAT1.

Fernandes et al. demonstrated that the in vivo application of SAX (Saxagliptin) loaded chitosan -L-valine resulted in enhanced drug delivery in the brain of rats compared to the suspension of SAX, which showed no detectable amount even after $24 \mathrm{~h}$. The SAX entrapped in the CSV was detected in the brain to the extent of $53.25 \pm 5.69 \mathrm{ng} / \mathrm{mL}$ at the end of $24 \mathrm{~h}$ [53].

Table 4. Biodistribution results of iron uptake in different studied organs of bulb/c mice bearing $4 \mathrm{~T} 1$ breast cancer cells $24 \mathrm{~h}$ after injection of USPION-tyrosine and USPION. The control group was bulb/c mice bearing 4T1 breast cancer cells without any injection of nanoparticles.

\begin{tabular}{l|l|l|l}
\multirow{2}{*}{ Tissue } & Tissue weighted(g) & Observed Dose-Control Dose(ppm) \\
\cline { 3 - 4 } & & USPIO & USPIO-Tyrosine \\
\hline Liver & $1.44260 \pm 0.3$ & $23.89 \pm 0.2$ & $12.126 \pm 0.5$ \\
\hline Spleen & $0.46508 \pm 0.1$ & $9.204 \pm 0.4$ & $12.470 \pm 0.6$ \\
\hline kidneys & $0.364318 \pm 0.5$ & $8.783 \pm 0.3$ & $0.693 \pm 0.3$ \\
\hline $\begin{array}{l}\text { Tumor } \\
* * * * p \text { value }>0.0001(\mathrm{n}=3, \text { mean } \pm \text { SD) }\end{array}$ & $5.905 \pm 0.18$ & $41.255 \pm 0.6$ \\
\end{tabular}

\section{Conclusions}

Early diagnosis of breast cancer has a significant effect on the survival rate of patients. There is an essential need to discover new tumor-specific contrast agents with high sensitivity and specificity and no toxicity to target tumor cell-based upon tumor-specific features at molecular levels. The novel, powerful biomarkers need to be addressed for insights into breast cancer detection. Many investigations have confirmed that tumors can be distinguished with high sensitivity and specificity by imaging their increased metabolic rates for amino acids, 
glucose, or lipids. In this study, we employed the potential of LAT1 transporter-targeted nanoparticles as an amino acid-based imaging probe for breast cancer imaging. We explored the molecular magnetic resonance imaging modality, using a LAT1 targeted magnetic nanoprobe that was synthesized with tyrosine as a LAT1 substrate coupled to USPION to target the LAT1 transporter that is highly expressed by most of breast tumor cells.

Results of in vitro and in vivo studies demonstrated that a specific diagnosis ability of USPION-tyrosine to the LAT1 expressing cells is possible. The results of cellular uptake studies via the Prussian Blue staining test, ICP-OES, and assessment of the reduction of signal intensity using MRI showed high targeting and specificity of USPIO-tyrosine conjugate to LAT1-positive breast cancer cells. In addition, in vivo MRI imaging of Bulb/c mice bearing 4T1 breast cancer cells demonstrated that tyrosine-conjugated USPION with high specificity, sensitivity, and no toxicity has the potential to be suggested as a targeted MR contrast agent for breast cancer detection at an early stage.

Our findings, together with that of other researches with LAT1 transporter-targeted nanoparticles, demonstrated the definitive potential to transfer across biological barriers with high uptake of contrast agents and therapeutic drugs in the targeted cell with high sensitivity and specificity.

Our findings open a promising view of breast cancer diagnosis and treatment with high sensitivity and specificity. As LAT1 is often upregulated in many cancer cells, this targeted nanoprobe can also be suggested also for the targeted imaging of a wide range of cancer types with high expression of LAT1.

\section{Funding}

This research received no external funding.

\section{Acknowledgments}

The author thanks Dr.Cordula Grüttner (Micromod Partikel Technologie GmbH, Rostock, Germany) for help and her discussion and meticulous guidance during this work. This research is particularly a Ph.D. thesis of Rahimeh Rasouli and was supported by International Campus, Tehran University of Medical Sciences (Grant no. 94-01-103-28528).

\section{Conflicts of Interest}

The authors declare no conflict of interest.

\section{References}

1. Danhier, F.; Feron, O.; Préat, V. To exploit the tumor microenvironment: passive and active tumor targeting of nanocarriers for anti-cancer drug delivery. Journal of Controlled Release 2010, 148, 135-146, https://doi.org/10.1016/j.jconrel.2010.08.027

2. R King, E.; Wong, K.-K. Insulin-like growth factor: current concepts and new developments in cancer therapy. Recent patents on anti-cancer drug discovery 2012, 7, 14-30, https://doi.org/10.1016/j.jconrel.2010.08.027.

3. Weir, H.K.; Thun, M.J.; Hankey, B.F.; Ries, L.A.; Howe, H.L.; Wingo, P.A.; Jemal, A.; Ward, E.; Anderson, R.N.; Edwards, B.K. Annual report to the nation on the status of cancer, 1975-2000, featuring the uses of surveillance data for cancer prevention and control. Journal of the National Cancer Institute 2003, 95, 12761299, https://doi.org/10.1093/jnci/djg040.

4. Coughlin, S.S.; Ekwueme, D.U. Breast cancer as a global health concern. Cancer epidemiology 2009, 33, 315-318, https://doi.org/10.1016/j.canep.2009.10.003. 
5. Jemal, A.; Bray, F.; Center, M.M.; Ferlay, J.; Ward, E.; Forman, D. Global cancer statistics. CA: a cancer journal for clinicians 2011, 61, 69-90, 69-90, http://dx.doi.org/10.3322/caac.20073.

6. Jemal, A.; Siegel, R.; Xu, J.; Ward, E. Cancer statistics, 2010. CA: a cancer journal for clinicians 2010, 60, 277-300, https://doi.org/10.3322/caac.20073.

7. Krasikova, R.N.; Kuznetsova, O.F.; Fedorova, O.S.; Belokon, Y.N.; Maleev, V.I.; Mu, L.; Ametamey, S.; Schubiger, P.A.; Friebe, M.; Berndt, M. 4-[18F] fluoroglutamic acid (BAY 85-8050), a new amino acid radiotracer for PET imaging of tumors: synthesis and in vitro characterization. Journal of medicinal chemistry 2010, 54, 406-410, https://doi.org/10.1021/jm101068q.

8. Cobleigh, M.A.; Vogel, C.L.; Tripathy, D.; Robert, N.J.; Scholl, S.; Fehrenbacher, L.; Wolter, J.M.; Paton, V.; Shak, S.; Lieberman, G. Multinational study of the efficacy and safety of humanized anti-HER2 monoclonal antibody in women who have HER2-overexpressing metastatic breast cancer that has progressed after chemotherapy for metastatic disease. Journal of Clinical Oncology 1999, 17, 2639-2639, https://doi.org/10.1200/jco.1999.17.9.2639.

9. Pegram, M.D.; Pauletti, G.; Slamon, D.J. HER-2/neu as a predictive marker of response to breast cancer therapy. Breast cancer research and treatment 1998, 52, 65-77, https://doi.org/10.1023/A:1006111117877.

10. YAMASAKI, S. Estrogen receptor in malignant and benign breast tumors and normal breast tissues of Japanese patients. Japanese Journal of Clinical Oncology 1978, 8, 37-47, https://doi.org/10.1093/oxfordjournals.jjco.a039903

11. Kong, F. Novel Amino Acid Transporter-Targeted Radiotracers for Breast Cancer Imaging. 2011.

12. Cheson, B.D.; Pfistner, B.; Juweid, M.E.; Gascoyne, R.D.; Specht, L.; Horning, S.J.; Coiffier, B.; Fisher, R.I.; Hagenbeek, A.; Zucca, E. Revised response criteria for malignant lymphoma. Journal of Clinical Oncology 2007, 25, 579, https://doi.org/10.1200/jco.2006.09.2403.

13. Kelloff, G.J.; Hoffman, J.M.; Johnson, B.; Scher, H.I.; Siegel, B.A.; Cheng, E.Y.; Cheson, B.D.; O'Shaughnessy, J.; Guyton, K.Z.; Mankoff, D.A. Progress and promise of FDG-PET imaging for cancer patient management and oncologic drug development. Clinical Cancer Research 2005, 11, 2785-2808, https://doi.org/10.1158/1078-0432.ccr-04-2626

14. Delbeke, D.; Coleman, R.E.; Guiberteau, M.J.; Brown, M.L.; Royal, H.D.; Siegel, B.A.; Townsend, D.W.; Berland, L.L.; Parker, J.A.; Hubner, K. Procedure guideline for tumor imaging with 18F-FDG PET/CT 1.0. Journal of Nuclear Medicine 2006, 47, 885-895, https://doi.org/10.1007/s00259-009-1297-4

15. von Schulthess, G.K.; Steinert, H.C.; Hany, T.F. Integrated PET/CT: current applications and future directions. Radiology 2006, 238, 405-422, https://doi.org/10.1148/radiol.2382041977

16. Plathow, C.; Weber, W.A. Tumor cell metabolism imaging. Journal of Nuclear Medicine 2008, 49, 43S63S, https://doi.org/10.2967/jnumed.107.045930.

17. Christensen, H.N. Role of amino acid transport and countertransport in nutrition and metabolism. Physiological reviews 1990, 70, 43-77, https://doi.org/10.1152/physrev.1990.70.1.43.

18. Ljungdahl, P.O.; Daignan-Fornier, B. Regulation of amino acid, nucleotide, and phosphate metabolism in Saccharomyces cerevisiae. Genetics 2012, 190, 885-929, https://doi.org/10.1534/genetics.111.133306.

19. del Amo, E.M.; Urtti, A.; Yliperttula, M. Pharmacokinetic role of L-type amino acid transporters LAT1 and LAT2. european journal of pharmaceutical sciences 2008, 35, 161-174, https://doi.org/10.1016/j.ejps.2008.06.015.

20. Russell, H.; Taylor, P.M.; Hundal, H.S. Amino acid transporters: roles in amino acid sensing and signalling in animal cells. Biochemical Journal 2003, 373, 1-18, https://doi.org/10.1042/bj20030405.

21. Johnstone, R.; Scholefield, P. Amino acid transport in tumor cells. In Advances in cancer research, Elsevier: 1965; Vol. 9, pp. 143-226, https://doi.org/10.1016/S0065-230X(08)60447-9.

22. Souba, W.W.; Pacitti, A.J. How amino acids get into cells: mechanisms, models, menus, and mediators. Journal of Parenteral and Enteral Nutrition 1992, 16, 569-578, https://doi.org/10.1177/0148607192016006569.

23. Lin, J.; Raoof, D.A.; Thomas, D.G.; Greenson, J.K.; Giordano, T.J.; Robinson, G.S.; Bourner, M.J.; Bauer, C.T.; Orringer, M.B.; Beer, D.G. L-type amino acid transporter-1 overexpression and melphalan sensitivity in Barrett's adenocarcinoma. Neoplasia 2004, 6, 74-84, https://doi.org/10.1016/S1476-5586(04)80054-X.

24. Nawashiro, H.; Otani, N.; Shinomiya, N.; Fukui, S.; Ooigawa, H.; Shima, K.; Matsuo, H.; Kanai, Y.; Endou, $\mathrm{H}$. L-type amino acid transporter 1 as a potential molecular target in human astrocytic tumors. International journal of cancer 2006, 119, 484-492, https://doi.org/10.1002/ijc.21866.

25. Nawashiro, H.; Otani, N.; Shinomiya, N.; Fukui, S.; Nomura, N.; Yano, A.; Shima, K.; Matsuo, H.; Kanai, Y. The role of CD98 in astrocytic neoplasms. Human cell 2002, 15, 25-31, https://doi.org/10.1002/ijc.21866.

26. Yoon, J.H.; Kim, I.J.; Kim, H.; Kim, H.-J.; Jeong, M.J.; Ahn, S.G.; Kim, S.A.; Lee, C.H.; Choi, B.K.; Kim, J.-K. Amino acid transport system $\mathrm{L}$ is differently expressed in human normal oral keratinocytes and human oral cancer cells. Cancer letters 2005, 222, 237-245, https://doi.org/10.1016/j.canlet.2004.09.040

27. Nakanishi, K.; Matsuo, H.; Kanai, Y.; Endou, H.; Hiroi, S.; Tominaga, S.; Mukai, M.; Ikeda, E.; Ozeki, Y.; Aida, S. LAT1 expression in normal lung and in atypical adenomatous hyperplasia and adenocarcinoma of the lung. Virchows Archiv 2006, 448, 142-150, https://doi.org/10.1007/s00428-005-0063-7.

28. Kobayashi, H.; Ishii, Y.; Takayama, T. Expression of L-type amino acid transporter 1 (LAT1) in esophageal carcinoma. Journal of surgical oncology 2005, 90, 233-238, https://doi.org/10.1002/jso.20257. 
29. Kim, S.-G.; Kim, H.-H.; Kim, H.-K.; Kim, C.-H.; Chun, H.S.; Kanai, Y.; Endou, H.; Do Kyung, K. Differential expression and functional characterization of system L amino acid transporters in human normal osteoblast cells and osteogenic sarcoma cells. Anticancer research 2006, 26, 1989-1996,

30. Yoon, J.H.; Kim, Y.B.; Kim, M.S.; Park, J.C.; Kook, J.K.; Jung, H.M.; Kim, S.G.; Yoo, H.; Ko, Y.M.; Lee, S.H. Expression and functional characterization of the system L amino acid transporter in KB human oral epidermoid carcinoma cells. Cancer letters 2004, 205, 215-226, https://doi.org/10.1016/j.canlet.2003.10.009.

31. Kaira, K.; Oriuchi, N.; Imai, H.; Shimizu, K.; Yanagitani, N.; Sunaga, N.; Hisada, T.; Ishizuka, T.; Kanai, Y.; Endou, H. Prognostic significance of L-type amino acid transporter 1 (LAT1) and 4F2 heavy chain (CD98) expression in early stage squamous cell carcinoma of the lung. Cancer science 2009, 100, 249-254.

32. Kaira, K.; Oriuchi, N.; Imai, H.; Shimizu, K.; Yanagitani, N.; Sunaga, N.; Hisada, T.; Kawashima, O.; Iijima, H.; Ishizuka, T. Expression of L-type amino acid transporter 1 (LAT1) in neuroendocrine tumors of the lung. Pathology-Research and Practice 2008, 204, 553-561, https://doi.org/10.1016/j.prp.2008.02.003.

33. Yanagida, O.; Kanai, Y.; Chairoungdua, A.; Kim, D.K.; Segawa, H.; Nii, T.; Cha, S.H.; Matsuo, H.; Fukushima, J.-i.; Fukasawa, Y. Human L-type amino acid transporter 1 (LAT1): characterization of function and expression in tumor cell lines. Biochimica et Biophysica Acta (BBA)-Biomembranes 2001, 1514, 291302, https://doi.org/10.1016/S0005-2736(01)00384-4.

34. Kanai, Y.; Segawa, H.; Miyamoto, K.-i.; Uchino, H.; Takeda, E.; Endou, H. Expression cloning and characterization of a transporter for large neutral amino acids activated by the heavy chain of 4F2 antigen (CD98). Journal of Biological Chemistry 1998, 273, 23629-23632, https://doi.org/10.1074/jbc.273.37.23629.

35. Mastroberardino, L.; Spindler, B.; Pfeiffer, R.; Skelly, P.J.; Loffing, J.; Shoemaker, C.B.; Verrey, F. Aminoacid transport by heterodimers of 4F2hc/CD98 and members of a permease family. Nature 1998, 395, 288, https://doi.org/10.1038/26246

36. Ohkame, H.; Masuda, H.; Ishii, Y.; Kanai, Y. Expression of L-type amino acid transporter 1 (LAT1) and 4F2 heavy chain (4F2hc) in liver tumor lesions of rat models. Journal of surgical oncology 2001, 78, 265272, https://doi.org/10.1002/jso.1165.

37. Kharya, P.; Jain, A.; Gulbake, A.; Shilpi, S.; Jain, A.; Hurkat, P.; Majumdar, S.; Jain, S.K. Phenylalaninecoupled solid lipid nanoparticles for brain tumor targeting. Journal of nanoparticle research 2013, 15, 1-12, https://doi.org/10.1007/s11051-013-2022-6.

38. Rautio, J.; Laine, K.; Gynther, M. Enhanced brain drug delivery and targeting. Pharmaceutical Technology Europe 2008, 1, 3.

39. Misra, A.; Ganesh, S.; Shahiwala, A.; Shah, S.P. Drug delivery to the central nervous system: a review. $J$ Pharm Pharm Sci 2003, 6, 252-273.

40. Boado, R.J.; Li, J.Y.; Nagaya, M.; Zhang, C.; Pardridge, W.M. Selective expression of the large neutral amino acid transporter at the blood-brain barrier. Proceedings of the National Academy of Sciences 1999, 96, 12079-12084, https://doi.org/10.1073/pnas.96.21.12079.

41. Shennan, D.B.; Thomson, J.; Barber, M.; Travers, M. Functional and molecular characteristics of system L in human breast cancer cells. Biochimica et Biophysica Acta (BBA)-Biomembranes 2003, 1611, 81-90, https://doi.org/10.1016/S0005-2736(03)00028-2.

42. Shennan, D.B.; Thomson, J. Inhibition of system L (LAT1/CD98hc) reduces the growth of cultured human breast cancer cells. Oncology reports 2008, 20, 885-889.

43. Travers, M.; Gow, I.F.; Barber, M.; Thomson, J.; Shennan, D.B. Indoleamine 2, 3-dioxygenase activity and L-tryptophan transport in human breast cancer cells. Biochimica et Biophysica Acta (BBA)-Biomembranes 2004, 1661, 106-112, https://doi.org/10.1016/j.bbamem.2003.12.004.

44. Shennan, D.B.; Thomson, J.; Gow, I.F.; Travers, M.; Barber, M. L-leucine transport in human breast cancer cells (MCF-7 and MDA-MB-231): kinetics, regulation by estrogen and molecular identity of the transporter. Biochimica et Biophysica Acta (BBA)-Biomembranes 2004, 1664, 206-216, https://doi.org/10.1016/j.bbamem.2004.05.008.

45. Liang, Z.; Cho, H.T.; Williams, L.; Zhu, A.; Liang, K.; Huang, K.; Wu, H.; Jiang, C.; Hong, S.; Crowe, R. Potential biomarker of L-type amino acid transporter 1 in breast cancer progression. Nuclear medicine and molecular imaging 2011, 45, 93-102, https://doi.org/10.1007/s13139-010-0068-2.

46. Kong, F.-L.; Zhang, Y.; Ali, M.S.; Oh, C.; Mendez, R.; Kohanim, S.; Tsao, N.; Chanda, M.; Huang, W.-C.; Yang, D.J. Synthesis of 99mTc-EC-AMT as an imaging probe for amino acid transporter systems in breast cancer. Nuclear medicine communications https://doi.org/10.1097/MNM.0b013e328339ea48.

47. Khosravian, P.; Ardestani, M.S.; Khoobi, M.; Ostad, S.N.; Dorkoosh, F.A.; Javar, H.A.; Amanlou, M. Mesoporous silica nanoparticles functionalized with folic acid/methionine for active targeted delivery of docetaxel. OncoTargets and therapy 2016, 9, 7315, https://doi.org/10.2147/OTT.S113815.

48. Khosroshahi, A.; Amanlou, M.; Sabzevari, O.; Daha, F.; Aghasadeghi, M.; Ghorbani, M.; Ardestani, M.; Alavidjeh, M.; Sadat, S.; Pouriayevali, M. A comparative study of two novel nanosized radiolabeled analogues of methionine for SPECT tumor imaging. Current medicinal chemistry 2013, 20, 123-133, https://doi.org/10.2174/0929867311302010012. 
49. Hashempour Alamdari, N.; Alaei-Beirami, M.; Shandiz, S.; Ataollah, S.; Hejazinia, H.; Rasouli, R.; Saffari, M.; Sadat Ebrahimi, S.E.; Assadi, A.; Shafiee Ardestani, M. Gd3. Contrast media \& molecular imaging 2017, 2017, https://doi:10.3390/ijms20102428.

50. Keshavarz, A.; Hajbabaei, S.; Sojoodi, J.; Saffari, M.; Afshar, M.A.A.; Monnavari, F.; Pargoo, E.M.; Rasouli, R.; Hejazinia, H.; Assadi, A. Mn 2+-Negatively Charged Pegylated Dendrimer G2-Tryptophan: Novel Nano Magnetic Resonance Imaging Agent. Advances in Applied Physiology 2017, 2, 1, https://doi.org/10.11648/j.aap.20170201.11.

51. Li, L.; Di, X.; Wu, M.; Sun, Z.; Zhong, L.; Wang, Y.; Fu, Q.; Kan, Q.; Sun, J.; He, Z. Targeting tumor highly-expressed LAT1 transporter with amino acid-modified nanoparticles: toward a novel active targeting strategy in breast cancer therapy. Nanomedicine: Nanotechnology, Biology and Medicine 2017, 13, 987-998, https://doi.org/10.1016/j.nano.2016.11.012.

52. Li, L.; Di, X.; Zhang, S.; Kan, Q.; Liu, H.; Lu, T.; Wang, Y.; Fu, Q.; Sun, J.; He, Z. Large amino acid transporter 1 mediated glutamate modified docetaxel-loaded liposomes for glioma targeting. Colloids and Surfaces B: Biointerfaces 2016, 141, 260-267, https://doi.org/10.1016/j.colsurfb.2016.01.041.

53. Fernandes, J.; Ghate, M.V.; Mallik, S.B.; Lewis, S.A. Amino acid conjugated chitosan nanoparticles for the brain targeting of a model dipeptidyl peptidase-4 inhibitor. International journal of pharmaceutics $\mathbf{2 0 1 8 ,}$ https://doi.org/10.1016/j.ijpharm.2018.06.031

54. Ong, Z.Y.; Chen, S.; Nabavi, E.; Regoutz, A.; Payne, D.J.; Elson, D.S.; Dexter, D.T.; Dunlop, I.E.; Porter, A.E. Multibranched gold nanoparticles with intrinsic LAT-1 targeting capabilities for selective photothermal therapy of breast cancer. ACS applied materials \& interfaces 2017, 9, 39259-39270, https://doi.org/10.1021/acsami.7b14851.

55. Gonzalez-Carter, D.A.; Ong, Z.Y.; McGilvery, C.M.; Dunlop, I.E.; Dexter, D.T.; Porter, A.E. L-DOPA functionalized, multi-branched gold nanoparticles as brain-targeted nano-vehicles. Nanomedicine: Nanotechnology, Biology and Medicine 2019, 15, 1-11, , https://doi.org/10.1016/j.nano.2018.08.011.

56. Maekawa-Matsuura, M.; Fujieda, K.; Maekawa, Y.; Nishimura, T.; Nagase, K.; Kanazawa, H. LAT1targeting thermoresponsive liposomes for effective cellular uptake by cancer cells. ACS Omega 2019, 4, 6443-6451, https://doi.org/10.1021/acsomega.9b00216.

57. Wang, D.; Zhao, Q.; Jiang, T.; Sha, L.; Wang, S.; Song, Y. Large amino acid transporter 1 mediated glutamate modified mesoporous silica nanoparticles for chemophotothermal therapy. Journal of Drug Delivery Science and Technology 2019, 52, 784-793, https://doi.org/10.1016/j.jddst.2019.05.043.

58. Puris, E.; Gynther, M.; Auriola, S.; Huttunen, K.M. L-Type amino acid transporter 1 as a target for drug delivery. Pharmaceutical Research 2020, 37, https://doi.org/10.1007/s11095-020-02826-8.

59. Elena, P.; Mikko, G.; Seppo, A.; Huttunen, K.M. L-Type amino acid transporter 1 as a target for drug delivery. Pharmaceutical Research 2020, 37, https://doi.org/10.1007/s11095-020-02826-8.

60. Zhang, L.; Sui, C.; Yang, W.; Luo, Q. Amino acid transporters: Emerging roles in drug delivery for tumortargeting therapy. Asian Journal of Pharmaceutical Sciences 2020, https://doi.org/10.1016/j.ajps.2019.12.002.

61. Häfliger, P.; Charles, R.-P. The L-type amino acid transporter LAT1-An emerging target in cancer. International journal of molecular sciences 2019, 20, 2428, https://doi.org/10.3390/ijms20102428.

62. Mészáros, M. Targeting the blood-brain barrier with solid and vesicular nanoparticles decorated with ligands of solute carriers. szte, 2019, https://doi.org/10.14232/phd.10157.

63. Kharya, P.; Jain, A.; Gulbake, A.; Shilpi, S.; Jain, A.; Hurkat, P.; Majumdar, S.; Jain, S.K. Phenylalaninecoupled solid lipid nanoparticles for brain tumor targeting. Journal of nanoparticle research 2013, 15, 20225, https://doi.org/10.1007/s11051-013-2022-6.

64. Vyas, A.; Jain, A.; Hurkat, P.; Jain, A.; Jain, S.K. Targeting of AIDS related encephalopathy using phenylalanine anchored lipidic nanocarrier. Colloids and Surfaces B: Biointerfaces 2015, 131, 155-161, https://doi.org/10.1016/j.colsurfb.2015.04.049.

65. Sharma, A.K.; Keservani, R.K.; Kesharwani, R.K. Nanobiomaterials: applications in drug delivery; CRC Press: 2018.

66. Urakami, T.; Sakai, K.; Asai, T.; Fukumoto, D.; Tsukada, H.; Oku, N. Evaluation of O-[18F] fluoromethyld-tyrosine as a radiotracer for tumor imaging with positron emission tomography. Nuclear medicine and biology 2009, 36, 295-303, https://doi.org/10.1016/j.nucmedbio.2008.12.012.

67. Kong, F.-L.; Zhang, Y.; Young, D.P.; Yu, D.-F.; Yang, D.J. Development of 99mTc-EC-tyrosine for early detection of breast cancer tumor response to the anticancer drug melphalan. Academic radiology 2013, 20, 41-51, https://doi.org/10.1016/j.acra.2012.08.005.

68. Wiriyasermkul, P.; Nagamori, S.; Tominaga, H.; Oriuchi, N.; Kaira, K.; Nakao, H.; Kitashoji, T.; Ohgaki, R.; Tanaka, H.; Endou, H. Transport of 3-fluoro-L- $\alpha$-methyl-tyrosine by tumor-upregulated L-type amino acid transporter 1: a cause of the tumor uptake in PET. Journal of Nuclear Medicine 2012, 53, 1253-1261, https://doi.org/10.2967/jnumed.112.103069.

69. Kaira, K.; Oriuchi, N.; Otani, Y.; Shimizu, K.; Tanaka, S.; Imai, H.; Yanagitani, N.; Sunaga, N.; Hisada, T.; Ishizuka, T. Fluorine-18- $\alpha$-methyltyrosine positron emission tomography for diagnosis and staging of lung cancer: a clinicopathologic study. Clinical Cancer Research 2007, 13, 6369-6378, https://doi.org/10.1158/1078-0432.ccr-07-1294. 
70. Kaira, K.; Oriuchi, N.; Shimizu, K.; Imai, H.; Tominaga, H.; Yanagitani, N.; Sunaga, N.; Hisada, T.; Ishizuka, T.; Kanai, Y. Comparison of L-type amino acid transporter 1 expression and L-[3-18F]- $\alpha$-methyl tyrosine uptake in outcome of non-small cell lung cancer. Nuclear medicine and biology 2010, 37, 911-916.

71. Kole, A.C.; Nieweg, O.E.; Pruim, J.; Paans, A.M. Standardized uptake value and quantification of metabolism for breast cancer imaging with FDG and L-(1-(11) C) tyrosine PET. The Journal of Nuclear Medicine 1997, 38, 692, https://doi.org/10.1016/j.nucmedbio.2010.06.004.

72. Nozaki, S.; Nakatani, Y.; Mawatari, A.; Shibata, N.; Hume, W.E.; Hayashinaka, E.; Wada, Y.; Doi, H.; Watanabe, Y. 18 F-FIMP: a LAT1-specific PET probe for discrimination between tumor tissue and inflammation. Scientific reports 2019, 9, 1-9, https://doi.org/10.1038/s41598-019-52270-x.

73. Verhoeven, J.; Baguet, T.; Piron, S.; Pauwelyn, G.; Bouckaert, C.; Descamps, B.; Raedt, R.; Vanhove, C.; De Vos, F.; Goethals, I. 2-[18F] FELP, a novel LAT1-specific PET tracer, for the discrimination between glioblastoma, radiation necrosis and inflammation. Nuclear Medicine and Biology 2020, 82, 9-16, https://doi.org/10.1038/s41598-019-40013-X

74. von Schulthess, G.K.; Steinert, H.C.; Hany, T.F. Integrated PET/CT: current applications and future directions 1. Radiology 2006, 238, 405-422, https://doi.org/10.1148/radiol.2382041977.

75. Catana, C.; Wu, Y.; Judenhofer, M.S.; Qi, J.; Pichler, B.J.; Cherry, S.R. Simultaneous acquisition of multislice PET and MR images: initial results with a MR-compatible PET scanner. Journal of Nuclear Medicine 2006, 47, 1968-1976.

76. Weber, W.A.; Grosu, A.L.; Czernin, J. Technology insight: advances in molecular imaging and an appraisal of PET/CT scanning. Nature Clinical Practice Oncology 2008, 5, 160-170, https://doi.org/10.1038/ncponc1041.

77. Zhang, C.; Jugold, M.; Woenne, E.C.; Lammers, T.; Morgenstern, B.; Mueller, M.M.; Zentgraf, H.; Bock, M.; Eisenhut, M.; Semmler, W. Specific targeting of tumor angiogenesis by RGD-conjugated ultrasmall superparamagnetic iron oxide particles using a clinical 1.5-T magnetic resonance scanner. Cancer research 2007, 67, 1555-1562, https://doi.org/10.1158/0008-5472.can-06-1668.

78. Akbarian, S.; Sojoodi, J.; Monnavari, F.; Heidari, H.; Khosravian, P.; A Javar, H.; Assadi, A.; Rasouli, R.; Saffari, M.; AS Shandiz, S. Nano Conjugated PLGA-Chlorambucil: Synthesis In Vitro Anti Non-Hodgkin's Lymphoma Cellular Assay. Letters in Drug Design \& Discovery 2017, 14, 827-836, https://doi.org/10.2174/1570180814666161130113446.

79. Rasouli, R.; Barhoum, A.; Uludag, H. A review of nanostructured surfaces and materials for dental implants: surface coating, patterning and functionalization for improved performance. Biomaterials science 2018, 6, 1312-1338, https://doi.org/10.1039/C8BM00021B.

80. Kebriaezadeh, A.; Ashrafi, S.; Rasouli, R.; Ebrahimi, S.E.S.; Hamedani, M.P.; Assadi, A.; Saffari, M.; Ardestani, M.S. Gadobutrol-dendrimer effects on metastatic and apoptotic gene expression. Advances in nano research 2016, 4, 145-156, https://doi.org/10.12989/anr.2016.4.2.145.

81. Rasouli, R.; Hosseinian, Z.; Azarnoosh, A.; Mortazavi, M.; Akbarzadeh, A.. Evaluation of magnetic nanoparticles loaded with cisplatin performance on breast cancer in in vivo and in vitro studies. 2015.

82. Keshavarz, A.; Hajbabaei, S.; Sojoodi, J.; Saffari, M.; Afshar, M.A.A.; Monnavari, F.; Pargoo, E.M.; Rasouli, R.; Hejazinia, H.; Assadi, A. Mn 2+ negatively charged pegylated dendrimer G2-tryptophan: Novel nano magnetic resonance imaging agent. Adv Appl Physiol 2017, 2, 1-9, https://doi.org/10.11648/J.AAP.20170201.11.

83. Rasouli, R.; Barhoum, A.; Bechelany, M.; Dufresne, A. Nanofibers for Biomedical and Healthcare Applications. Macromolecular bioscience 2018, 1800256, https://doi.org/10.1002/mabi.201800256.

84. Rasouli, R.; Barhoum, A. Advances in Nanofibers for Antimicrobial Drug Delivery. Handbook of Nanofibers 2018, 1-42, https://doi.org/10.1007/978-3-319-53655-2_33.

85. Barhoum, A.; Rasouli, R.; Yousefzadeh, M.; Rahier, H.; Bechelany, M. Nanofiber Technology: History and Developments. Handbook of Nanofibers 2018, 1-42.

86. Rasouli, R.; Alikhani, Z.; Shafiee, A.M.; Faridi, M.R.; Ebrahimi, S.F. Nanotechnology In The Development Of Vaccines 2015.

87. Fathi, S.; Saber, R.; Adabi, M.; Rasouli, R.; Douraghi, M.; Morshedi, M.; Farid-Majidi, R. Novel Competitive Voltammetric Aptasensor Based on Electrospun Carbon Nanofibers-Gold Nanoparticles Modified Graphite Electrode for Salmonella enterica serovar Detection. Biointerface Research in Applied Chemistry 2021, 8702 - 8715, https://doi.org/10.33263/BRIAC112.87028715.

88. Hung, A.H.; Duch, M.C.; Parigi, G.; Rotz, M.W.; Manus, L.M.; Mastarone, D.J.; Dam, K.T.; Gits, C.C.; MacRenaris, K.W.; Luchinat, C. Mechanisms of gadographene-mediated proton spin relaxation. The Journal of Physical Chemistry C 2013, 117, 16263-16273, https://doi.org/10.1021/jp406909b.

89. Shahbazi-Gahrouei, D.; Abdolahi, M. Detection of MUC1-expressing ovarian cancer by C595 monoclonal antibody-conjugated SPIONs using MR imaging. The Scientific World Journal 2013, 2013, https://doi.org/10.1155/2013/609151.

90. Abdolahi, M.; Shahbazi-Gahrouei, D.; Laurent, S.; Sermeus, C.; Firozian, F.; Allen, B.J.; Boutry, S.; Muller, R.N. Synthesis and in vitro evaluation of MR molecular imaging probes using J591 mAb-conjugated SPIONs for specific detection of prostate cancer. Contrast media \& molecular imaging 2013, 8, 175-184, https://doi.org/10.1002/cmmi.1514. 
91. Shah, L.; Yadav, S.; Amiji, M. Nanotechnology for CNS delivery of bio-therapeutic agents. Drug delivery and translational research 2013, 3, 336-351, https://doi.org/10.1007/s13346-013-0133-3.

92. Pardridge, W.M. Re-engineering biopharmaceuticals for delivery to brain with molecular Trojan horses. Bioconjugate chemistry 2008, 19, 1327-1338, https://doi.org/10.1021/bc800148t.

93. Shanehsazzadeh, S.; Gruettner, C.; Lahooti, A.; Mahmoudi, M.; Allen, B.J.; Ghavami, M.; Daha, F.J.; Oghabian, M.A. Monoclonal antibody conjugated magnetic nanoparticles could target MUC-1-positive cells in vitro but not in vivo. Contrast media \& molecular imaging 2015, 10, 225-236, https://doi.org/10.1002/cmmi.1627.

94. Monteiro-Riviere, N.; Inman, A.; Zhang, L. Limitations and relative utility of screening assays to assess engineered nanoparticle toxicity in a human cell line. Toxicology and applied pharmacology 2009, 234, 222235, https://doi.org/10.1016/j.taap.2008.09.030.

95. Lin, W.; Huang, Y.-w.; Zhou, X.-D.; Ma, Y. In vitro toxicity of silica nanoparticles in human lung cancer cells. Toxicology and applied pharmacology 2006, 217, https://doi.org/10.1016/j.taap.2006.10.004.

96. Mahmoudi, M.; Simchi, A.; Milani, A.; Stroeve, P. Cell toxicity of superparamagnetic iron oxide nanoparticles. Journal of colloid and interface science 2009, 336, 510-518, https://doi.org/10.1016/j.jcis.2009.04.046.

97. Mehravi, B.; Ardestani, M.S.; Damercheli, M.; Soltanghoraee, H.; Ghanaldarlaki, N.; Alizadeh, A.M.; Oghabian, M.A.; Shirazi, M.S.; Mahernia, S.; Amanlou, M. Breast cancer cells imaging by targeting methionine transporters with gadolinium-based nanoprobe. Molecular Imaging and Biology 2014, 16, 519528, https://doi.org/10.1007/s11307-014-0718-3.

98. Xiong, F.; Zhu, Z.-y.; Xiong, C.; Hua, X.-q.; Shan, X.-h.; Zhang, Y.; Gu, N. Preparation, characterization of 2-deoxy-D-glucose functionalized dimercaptosuccinic acid-coated maghemite nanoparticles for targeting tumor cells. Pharmaceutical research 2012, 29, 1087-1097, https://doi.org/10.1007/s11095-011-0653-9.

99. Shahbazi-Gahrouei, D.; Williams, M.; Rizvi, S.; Allen, B. In vivo studies of Gd-DTPA-monoclonal antibody and gd-porphyrins: Potential magnetic resonance imaging contrast agents for melanoma. Journal of Magnetic Resonance Imaging: An Official Journal of the International Society for Magnetic Resonance in Medicine 2001, 14, 169-174, 169-174, https://doi.org/10.1002/jmri.1168. 